\title{
Purification and Partial Identification of Novel Antimicrobial Protein from Marine Bacterium Pseudoalteromonas Species Strain X153
}

\author{
Arlette Longeon ${ }^{1}$, Jean Peduzzi ${ }^{1}$, Michel Barthelemy ${ }^{1}$, Sophie Corre ${ }^{2}$, \\ Jean-Louis Nicolas ${ }^{3}$ and Michele Guyot ${ }^{1}$
}

(1) Laboratoire de Chimie et Biochimie des Substances Naturelles, UMR 5154 CNRS, Museum National d' Histoire Naturelle, USM 502, 63, rue Buffon, Paris, 75005, France

(2) Micromer Technopole Brest-Iroise, Brest, 29200, France

(3) Laboratoire de Physiologie des Invertebres, DRV, IFREMER, Plouzane, 29280, France

\author{
*: Corresponding author: Michele Guyot \\ Email: guyot@mnhn.fr \\ Phone: 33-1-40-79-31-42 \\ Fax: 33-1-40-79-31-35
}

\begin{abstract}
:
A marine bacterium, X153, was isolated from a pebble collected at St. Anne du Portzic (France). By $16 S$ ribosomal DNA gene sequence analysis, X153 strain was identified as a Pseudoalteromonas sp. close to $P$. piscicida. The crude culture of X153 was highly active against human pathogenic strains involved in dermatologic diseases, and marine bacteria including various ichthyopathogenic Vibrio strains. The active substance occurred both in bacterial cells and in culture supernatant. An antimicrobial protein was purified to homogeneity by a 4-step procedure using size-exclusion and ionexchange chromatography. The highly purified P-153 protein is anionic, and sodium dodecylsulfate polyacrylamide gel electrophoresis gives an apparent molecular mass of $87 \mathrm{kDa}$. The X153 bacterium protected bivalve larvae against mortality, following experimental challenges with ichthyopathogenic Vibrio. Pseudoalteromonas sp. X153 may be useful in aquaculture as a probiotic bacterium.
\end{abstract}

Keywords: antimicrobial protein - Pseudoalteromonas - probiotic bacteria 


\section{INTRODUCTION}

In the last few years marine microorganisms emerge as a new field for the discovery of novel biologically active compounds from marine origin (Fenical, 1993, 1997). Isolation of bacteria can originate mainly from sediments, but also from open oceans or marine surfaces including marine living organisms (Jensen and Fenical, 1994). Antibiotic production by marine bacteria has been documented for a long time (Rosenfeld et al., 1947; Baam et al., 1966). Since these earlier reports, many low molecular weight antibiotic substances have been isolated from marine bacteria (Faulkner, 2001). In contrast only few publications are dedicated to antibiotic proteins from marine bacteria whereas the bacteriocins produced by terrestrial bacteria are recognized to be an excellent source of antibiotic proteins and polypeptides (Tagg et al., 1976; Konisky, 1982; Klaenhammer, 1988) such as nisin and subtilin and are considered of significant interest in the food industry (Rayman et al., 1981; Delves-Broughton et al., 1996). Nevertheless, two antibiotic proteins with a molecular mass of approximately $100 \mathrm{kDa}$ were purified from Alteromonas strains (Barja et al., 1989; McCarthy et al., 1994) and an oligomeric 190-kDa protein was isolated from an unidentified biofilm-forming marine bacterium D2 (James et al., 1996).

Such antimicrobial strains may have an interest in aquaculture as probiotic or or by providing antimicrobial compounds specific for ichtyopathogenic strains. In aquaculture, the first probiotics tested in fish were those used for terrestrial animals, even though the results were variable (Verschuere et al, 2000;. Gomez-Gil et al., 2001; Olafsen, 2001). However survival of these bacteria in aquatic environment was uncertain (or problematic) and attempts have been undertaken to select probiotic strains from marine environment. To date they only belong to some genera including Vibrio, Aeromonas, Alteromonas and lactic acid bacteria (Gatesoupe, 1999, Verschuere et al 2000). Efficiency of these marine bacteria to enhance health were showed for some species such as fish (Olafsen, 2001), shrimp 
(Austin et al, 1995), bivalve (Ruiz-Ponte et al, 1999; Gibson et al, 1998). The mechanism of protection has not yet been investigated but it is probably complex including adhesion in mucus, competition for an ecological niche, antibacterial activity, immune stimulation. Marine bacteria (Austin et al., 1995; Ringø and Vadstein, 1998; Ruiz-Ponte et al., 1999), represent certainly a great potential reservoir not sufficiently investigated.

In a program devoted to the search of antimicrobial substances and probiotics usable in aquaculture and produced by marine bacteria, we investigate bacteria collected from different substrates on the littoral of Brittany. Our attention was focused upon a strain, Pseudoalteromonas sp., obtained at St Anne du Portzic (Brittany, France), the crude culture exhibiting high antimicrobial activity.

\section{MATERIAL AND METHODS}

\section{Isolation and Characterization of the Strain.}

The marine bacterium X153 was selected by ten-fold serial dilutions in Marine broth (Difco) of an isolate (18 strains) obtained by scratching a pebble, covered by Rhodophyceae and Chlorophyceae, and collected at St Anne du Portzic (Brittany, France).

Analysis of $16 \mathrm{~S}$ ribosomal DNA (rDNA) sequence was used to identify the X153 isolate. 16S rDNA was amplified by polymerase chain reaction (PCR) using the universal primers and sequenced. PCR was performed with bacterial 16S rDNA primers $8 f$ (5'AGAGTTTGATCCATGGC-3') and 1492R (5'-GTTACCTTGTTACGACTT-3') and the Taq polymerase (Appligene Oncor, Illkirch, France). The used PCR temperature profile was $95^{\circ} \mathrm{C}$ for $3 \mathrm{~min}$, followed by 30 cycles of $94^{\circ} \mathrm{C}$ for $30 \mathrm{~s}, 52^{\circ} \mathrm{C}$ for $1 \mathrm{~min}, 72^{\circ} \mathrm{C}$ for $90 \mathrm{~s}$ and a final extension step at $72^{\circ} \mathrm{C}$ for 5 min. Taq polymerase was removed by chloroform (2 vol.) then PCR amplicons were precipitated by $0.6 \mathrm{M}$ polyethylene glycol, $2 \mathrm{M} \mathrm{NaCl}$, 
and rinsed by $70 \%$ ethanol. DNA sequencing was performed by Genome express company (Meylan, France). The nucleotide sequence of the 16S rDNA from X153 strain has been deposited in the EMBL database under accession number AJ581533.

Search of nucleotide sequence homology of 16S rDNA gene were done using the Blast algorithm (Altschul et al., 1990) and then the sequences were aligned using ClustalW (Thompson et al., 1994) and MegAlign programs (Dnastar Inc., Madison, USA). Phylogenetic trees were built with the Phylowin program (Galtier et al, 1996) by using neighbour-joining method. The data set was boostrapped for 500 replications to consider the robustness of the internal nodes.

Different characteristics of the X153 strain were determined including Gram stain, motility, pigmentation and utilization of different carbon sources in Baumann medium (Baumann and Baumann, 1981).

\section{Microbial strains}

X153 spectrum of activity was established against microorganisms including Gramnegative and Gram-positive bacteria, as well as yeast strains and the filamentous fungus Aspergillus niger. Ten human pathogenic strains were used in this study: Enterobacter gergoviae (CIP 105140), Escherichia coli (ATCC 8739), Pseudomonas aeruginosa (ATCC 9027), Staphylococcus aureus (ATCC 6538P), Staphylococcus epidermis (CIP 6821), Propionibacterium acnes, Propionibacterium granulosum, Candida albicans (ATCC 10231), Pityrosporum ovale and A. niger. Twenty four marine bacteria strains were also tested among which seven ichthyopathogenic Vibrio strains (stars): Bacillus globi sp. marinus, Cytophaga lytica, Cytophaga marinoflava, Deleya marina, Halomonas elongata, Oceanospirillum jannaschii, Pseudomonas doudoroffi, Pseudomonas nautica,

*Vibrio alginolyticus, * Vibrio anguillarum (ATCC 19264), *Vibrio carchariae, Vibrio 
costicola, Vibrio damsela, Vibrio haloplanktis, Vibrio harveyi, Vibrio mediterranei, Vibrio natriegens, *Vibrio parahaemolyticus, *Vibrio pectenicida, Vibrio pelagius, Vibrio proteolyticus, *Vibrio splendidus, *Vibrio tapetis (P1), and Vibrio vulnificus. The strains without reference were from laboratory collection.

\section{Antimicrobial Assays}

A culture of X153 strain $(10 \mathrm{ml})$ in Marine broth for $48 \mathrm{~h}$ at $25^{\circ} \mathrm{C}$ was centrifuged at $4500 \mathrm{~g}$ for $15 \mathrm{~min}$. The supernatant was filter-sterilized $(0.2 \mu \mathrm{m})$ and the pellet was suspended in $10 \mathrm{ml}$ sterile water and sonicated in ice three times for $30 \mathrm{~s}$. The single-layer method was used to measure the antimicrobial activity of the crude culture. This method was a modification of the double-layer method (Schilinger and Lücke, 1980). Briefly, 25 $\mathrm{ml}$ of $0.7 \%$ agar $(\mathrm{w} / \mathrm{v})$ containing Marine broth, Mueller-Hinton or Sabouraud medium were inoculated with $250 \mu \mathrm{l}$ of a suspension of test strains $\left(10^{8}\right.$ cells per ml, measured by DO at $620 \mathrm{~nm})$, and then poured into plates. Wells $(5 \mathrm{~mm})$ are cut in the agar and filled with $50 \mu \mathrm{l}$ of X153 culture, filtered supernatant or sonicated cell suspension, each in six concentrations: crude, 1/2, 1/4, 1/8, 1/16 and 1/32 dilutions. The plates were examined for growth inhibition after 5 days of incubation at $25^{\circ} \mathrm{C}$ for $A$. niger, $48 \mathrm{~h}$ of incubation at $25^{\circ} \mathrm{C}$ for Vibrio and yeast strains or after $24 \mathrm{~h}$ of incubation at $37^{\circ} \mathrm{C}$ for the other Gramnegative and Gram-positive bacteria. Experiments were made in triplicate for the human strains and in duplicate for the marine strains.

During the purification procedure, antimicrobial activity was monitored by the disk diffusion method assay (Ruiz-Ponte et al., 1999) with S. aureus as susceptible strain. One unit of arbitrary antibacterial activity is defined as the amount of protein giving an inhibitory diameter of $15 \mathrm{~mm}$. Minimum inhibitory concentration (MIC) against S. aureus and $V$. anguillarum was determined using the disk diffusion assay. 


\section{Antimicrobial Protein Purification}

The Pseudoalteromonas sp. strain X 153 was cultivated in 1.4 l batches in Marine broth during 48 hours at $25^{\circ} \mathrm{C}$ and in static conditions. After centrifugation (4500 g, 15 min, $4^{\circ} \mathrm{C}$ ), the pellet was collected and the supernatant freeze-dried. Antibacterial activity was found both in the pellet and the supernatant, however for practical reasons, purification of the active compound termed P-153 was achieved from the bacterial cells.

All the purification steps were carried out at $4^{\circ} \mathrm{C}$. The bacterial pellet was extracted once with $100 \mathrm{ml}$ seawater and three times with $100 \mathrm{ml}$ deionized water followed by centrifugations at $15000 \mathrm{~g}$ for $30 \mathrm{~min}$. The crude extract was dialyzed against $0.1 \mathrm{M} \mathrm{NaCl}$ with a Spectra/Por 1 tubing (6-8000 molecular weight cut off) and then lyophilized. Aliquot fractions (35 mg proteins) of the dialysate was applied onto a Sephadex G 200 column $(3 \times 35 \mathrm{~cm})$ equilibrated with $25 \mathrm{mM}$ ammonium bicarbonate, $0.1 \mathrm{M} \mathrm{NaCl}$ and eluted with the same solution at a flow rate of $12 \mathrm{ml} \mathrm{h}^{-1}$. The active fractions were pooled, dialyzed against $0.1 \mathrm{M} \mathrm{NaCl}$ and then freeze-dried. Protein mixture from size-exclusion chromatography was fractionated by anion-exchange high performance liquid chromatography (HPLC) on a Mono Q HR5/5 column (Pharmacia), equilibrated with 20 mM Tris/HCl buffer, pH 7.8 (solvent A). Samples in the same buffer were loaded on the column and the proteins were eluted with a $1 \mathrm{M} \mathrm{NaCl,} 20 \mathrm{mM}$ Tris/HCl buffer $\mathrm{pH} 7.8$ as solvent B. A 30 min linear gradient from 20 to $60 \%$ solvent B in solvent A was used at a flow rate of $0.8 \mathrm{ml} \mathrm{min}^{-1}$. Finally the peak containing the antimicrobial activity $(0.45 \mathrm{M}$ $\mathrm{NaCl}$ ) was separated by size-exclusion HPLC on a Superdex 200 HR 10/30 (Pharmacia) equilibrated with $25 \mathrm{mM}$ ammonium bicarbonate, $0.15 \mathrm{M} \mathrm{NaCl}$ and eluted with the same solvent at a flow rate of $0.4 \mathrm{ml} \mathrm{min}^{-1}$. Pure P-153 protein was then desalted by using PD-10 
column (Pharmacia) eluted with MilliQ ${ }^{\mathrm{TM}}$ water. During all the chromatography steps, absorbance was monitored at $226 \mathrm{~nm}$.

\section{Molecular Mass Determination}

The homogeneity and the relative molecular mass in denaturing conditions were carried out by analytical polyacrylamide gel electrophoresis (SDS-PAGE) on a 4-15\% polyacrylamide gel as described by Laemmli (1970). After electrophoresis, proteins were visualized by silver staining and the molecular mass of P-153 was estimated using the MW-SDS 200 kit (Sigma). Purified P-153 protein (50 $\mu \mathrm{g}$ ) was subjected to size-exclusion HPLC on a Superose 6 HR 10/30 column (Pharmacia). Separation was performed at a flow rate of $0.3 \mathrm{ml} \mathrm{min}^{-1}$ under $25 \mathrm{mM}$ ammonium bicarbonate, $0.1 \mathrm{M} \mathrm{NaCl}$. Absorbance was monitored at $226 \mathrm{~nm}$. Gel filtration molecular mass markers (Sigma) used as standards were apoferritin (443 kDa), alcohol dehydrogenase (150 kDa), serum albumin bovine (66 $\mathrm{kDa})$ and carbonic anhydrase (29 kDa). Blue dextran (2000 kDa) was used to visualize the void volume.

\section{Amino Acid Analysis}

Samples of P-153 (3 nmol) were hydrolyzed at $110{ }^{\circ} \mathrm{C}$ under vacuum with $6 \mathrm{M} \mathrm{HCl}$ constant boiling (Sigma) for $24 \mathrm{~h}$. The resulting amino acids were separated on a cation exchange PC6A resin (Pierce) and the $o$-phthaldialdehyde derivatives of amino acids were detected with a Waters 420 fluorimeter. Proline was detected at $254 \mathrm{~nm}$ by reverse-phase HPLC of its phenylisothiocarbamate derivatives (Cohen and Strydom, 1988), using a Supelcosil LC18-DB column $(0.46 \times 15 \mathrm{~cm}, 3 \mu \mathrm{m}$; Supelco) as previously reported (Almeida et al. 2000). The serine and threonine contents of the hydrolysates were corrected for partial destruction during the hydrolysis by extrapolation to zero time hydrolysis. The 
amino acid composition, expressed as a mole percent, represents the average of two independent determinations and allows to determine the amount of purified P-153 protein.

\section{Larvae Toxicity}

Two tests were carried out to estimate the probiotic activity and larvae toxicity of Pseudoalteromonas sp. X153 strain. In a short assay, about 2-days old larvae of Manila clam (Ruditapes philippinarum) were distributed in a 24-well culture cell plate (approximately 50 larvae in $3 \mathrm{ml}$ of seawater per well) and exposed to 24 h-cultured X153 at different concentrations $\left(10^{5}, 10^{6}, 10^{7}\right.$ and $10^{8}$ cells per ml). A long-term effect of the probiotic was tested in culture of scallop (Pecten maximus) larvae in which mortality

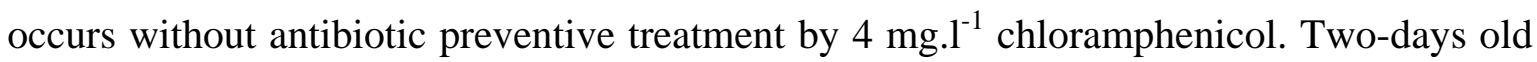
larvae were reared in $2 \mathrm{l}$ beakers at 5 larvae per ml according to the method described by Robert et al. (1994). The probiotic cultured in 1 g. $\mathrm{l}^{-1}$ casamino acids (CA, Merck) was centrifuged (4500 $\mathrm{g}$ for $15 \mathrm{~min}$ ), rinsed, distributed to larval culture in a final concentration of $10^{6}$ bacteria per $\mathrm{ml}$ and renewed at every change of one liter of seawater (3 times a week). This concentration appeared necessary in a preliminary experiment to produce an antagonism in seawater against pathogenic Vibrio isolated from diseased larvae. The size (major length) was automatically measured on a sample of larvae by imager processor. Mortality was determined by counting of alive and dead larvae in a sample of at least 200 larvae. For all experiments every condition was performed in triplicate. Comparisons between the larvae size in different batches were done by one-way analysis of variance (ANOVA) followed by the Fisher PLSD test at 5\% significance level. Percentages of mortality were often too different between replicates to be submitted to statistical analyses.

\section{RESULTS AND DISCUSSION}


The X153 strain was a mobile, catalase-positive, strict anaerobic Gram-negative bacterium, which forms compact yellow colonies. PCR amplification performed with universal bacterial 16S rDNA primers ( $8 f$ and $1492 \mathrm{R}$ ) produced a fragment of approximately 1400 bp. The sequence of 16S rDNA from X153 strain was almost completely determined and aligned against the nearest Blast sequences using the multiple-alignment ClustalW program. Phylogenetic analysis using 16S rDNA sequences and the neighbour-joining method showed the X153 strain is a member of Pseudoalteromonas close to P. piscicida, P. peptidysin and Pseudoalteromonas sp. named Y (Figure 1). This result clearly indicates that X153 strain is very close to a strain isolated in an estuary in Tasmania (Australia), Pseudoalteromonas sp. Y, which displayed an algicidal effect against harmful micro-algae (Lovejoy et al., 1998). The same phylogenetic tree was obtained with maximum likelihood and maximum parsimony methods. Although its $16 \mathrm{~S}$ rDNA sequence was almost identical to the one of P. piscicida (99.9\% identity) DNA/DNA hybridization would be necessary to confirm that both belong to the same species. Table 1 shows that some characteristics of the X153 strain are identical to those previously reported for P. piscicida (Vankateswaran and Dohomoto 2000; Ivanova et al. 2002) with the exception of the utilization of Dgalactose and succinate as carbon source.

The crude extract of X153 strain was not tested against harmful microalgae, but when X153 strain was introduced in axenic culture of Isochrisis galbana (var Tahiti) used to feed bivalve, a slow-down (but without breakdown) of T-iso culture was observed (data not shown). The activity of the crude extract of X153 strain was almost restricted to bacteria. Thus, only weak activity was observed against yeast strains (C. albicans and P. ovale) and no activity against the fungus (A. niger). On the contrary, X153 crude culture was highly active against several human pathogenic strains as well as marine bacteria, including the seven ichthyopathogenic Vibrio. Among the ten human pathogenic strains tested, two were 
not inhibited by X153 (E. gergoviae and A. niger), five were only inhibited by undiluted suspensions (E. coli, P. aeruginosa, S. aureus and the yeasts C. albicans and P. ovale). Three strains implied in dermatological diseases (S. epidermidis, $P$. acnes and $P$. granulosum) were inhibited until the $1 / 4$ or 1/8 dilution (Table 2). Antibacterial activity of the isolate X153 was markedly stronger against marine strains. All the strains tested were susceptible to X153 crude extract and the seven ichthyopathogenic Vibrio strains were susceptible until the $1 / 2$ or $1 / 16$ dilution (Table 3). Tables 2 and 3 also show that biological activity is present in the bacterial cells, but also in the culture supernatant. Comparison of the activity of the freeze-dried pellet extract and the freeze-dried supernatant from 1.4 liter culture, after dialysis, showed antimicrobial activity in both, but the antimicrobial activity was highest in the pellet. So, we can't exclude the possibility of the presence of lowmolecular weight compounds in the supernatant.

Hence the antimicrobial compound was purified from bacterial cells, until homogeneity, by a four-step procedure. Crude antimicrobial extracts were obtained from one liter X153 culture grown in Marine broth. From the bacterial pellet, usually $150 \mathrm{mg}$ of proteins were extracted (4000 U). After the three steps of size-exclusion and anionexchange chromatography, $300 \mu \mathrm{g}$ of highly purified P-153 were obtained with a specific activity of $600 \mathrm{U} / \mathrm{mg}$. MIC toward S. aureus and V. anguillarum was $0.3 \mathrm{nM}$.

Protein homogeneity was determined by SDS-PAGE, which indicated a purity superior to $95 \%$ and an apparent mass of $87 \mathrm{kDa}$ (Fig. 2A). When determined by size-exclusion chromatography on Superose 6 column, the molecular mass of P-153 was approximately $280 \mathrm{kDa}$ (Fig. 2B). This suggests that in aqueous solution, the antimicrobial protein likely forms trimers. Such a characteristic is similar to the oligomeric structure of the antibacterial protein purified from the marine bacterium D2 (James et al., 1996). The amino acid composition of purified P-153 is shown in Table 4. The P-153 protein was 
characterized by a high content in aspartic and glutamic acids (near to 26 mole percent) and serine (15.6 mole percent) and exhibited a charged to hydrophobic ratio (C/HP; Asx, Glx, His, Arg, Lys / Ala, Pro, Val, Met, Ile, Leu, Phe) of 1.08. The anionic nature of P-153 explains its retention time on the anion-exchange MonoQ column and the $0.45 \mathrm{M} \mathrm{NaCl}$ concentration required to elute the protein from the column. However, when highly purified, the protein P-153 was very unstable. Several attempts to stabilize the protein by salts or BSA addition failed.

The Pseudoalteromonas sp. X153 strain was not toxic for bivalve larvae in the shortterm assay in cell culture plate. After $24 \mathrm{~h}$ of incubation with X153, the Manila clam larvae exhibited the same behavior as the control until $10^{7}$ cells.ml ${ }^{-1}$. In the long-term assay, growth and mortality of scallop larvae treated by probiotic bacteria X153, were measured 16 and 19 days after hatching (Table 5). The probiotic protected the larvae against mortality: the mortality rates of larvae were 4-fold reduced in the presence of X153 after 16 days compared with the control without antibiotic. After 19 days, when metamorphosis started, mortality was only $6 \%$ of larvae died in comparison with $28.3 \%$ in the control without antibiotic. However the probiotic bacterium reduced the growth rate approximately from $5 \%$ at day 16 to $10 \%$ at day 19 compared with the controls with or without chloramphenicol (Table 5). The probiotic effect appeared efficient, although slightly inferior to that of chloramphenicol. The slow down of growth, was not necessary due to the antibacterial protein. Unfortunately the instability of the purified P-153 protein and the difficulty to purify sufficient amounts $(>10 \mathrm{mg}$ ) prevented to test it on scallop larvae culture. Additional experiments will be necessary to conclude about the interest of this bacterium as probiotic. It could be more promising for shrimp and fish rearing than for bivalve larval culture. In conclusion, thehigh antibacterial activity of the antibacterial protein P-153 against S. epidermidis and Propionibacterium tested strains, suggests an 
interest in human health for dermatological diseases. On the other hand, in the aquaculture area the broad spectrum of activity of Pseudoalteromonas sp. X153 strain especially against ichthyopathogenic Vibrio, allows to consider its use as a probiotic bacterium in various rearing.

\section{ACKNOWLEDGMENTS}

We thank C. Deregnaucourt (USM 504, Muséum National d'Histoire Naturelle) for SDSPAGE. This work was supported in part by the program 97.C.0111 "Recherche de nouveaux agents antibiotiques et probiotiques dans les bactéries marines" of the French ministry for Research and Technology.

\section{REFERENCES}

Almeida, M.J., Milet, C., Peduzzi, J., Pereira, L., Haigle, J., Barthélémy, M., and Lopez, E. (2000). Effect of water-soluble matrix fraction extracted from the nacre of Pinctada maxima on the alkaline phosphatase activity of cultured fibroblasts. $J$ Exp Zool 288: 32734.

Altschul, S.F., Gish, W., Miller, W., Myers, E.W., and Lipman, D.J. (1990). Basic local alignment search tool. J Mol Biol 215:403-410.

Austin, B., Stuckey, L.F., Robertson, P.A.W., Effendi, I., and Griffith, D.R.W. (1995). A probiotic strain of Vibrio alginolyticus effective in reducing diseases caused by Aeromonas salmonicida, Vibrio anguillarum and Vibrio ordalii. J Fish Dis 18:93-96.

Baam, B.R., Gandhi, N.M., and Freitas, Y.M.. (1966). Antibiotic activity of marine microorganisms. Helgol Wiss Meeresunters 13:181-185. 
Barja, J.L., Lemos, M.L., and Toranzo, A. (1989). Purification and characterization of an antibacterial substance produced by a marine Alteromonas species. Antimicrob Agents Chemother 33:1674-1679.

Baumann, P., and Baumann, L. (1981). The marine Gram negative eubacteria: genera Photobacterium, Benekea, Alteromonas and Pseudomonas. In: The Prokayotes vol. 2, Starr, M..P., Stolp, H., Trüper, H.G., Baloows, A., Schleger, H.G. (eds). Berlin, SpringerVerlag: 1302-1331.

Cohen, S.A., and Strydom, D.J. (1988). Amino acid analyses utilizing phenylisothiocyanate derivatives. Anal Biochem 174:1-16.

Delves-Broughton, J., Blackburn, P., Evans, R.J., and Hugenholtz, J. (1996). Applications of the bacteriocin, nisin. Antonie Van Leeuwenhoek 69:193-202.

Faulkner, D.J. (2001). Marine natural products. Nat Prod Rep 18:1-49.

Fenical, W. (1993). Chemical studies of marine bacteria: developing a new resource. Chem $\operatorname{Rev}$ 93:1673-1683.

Fenical, W. (1997). New pharmaceuticals from marine organisms. Trends Biotechnol 15:339-341.

Galtier, N., Gouy, M., and Gautier, C. (1996). SEAVIEW and PHYLO_WIN: two graphic tools for sequence alignment and molecular phylogeny. Comput Appl Biosci 12:543-548.

Gatesoupe, FJ. (1999). The use of probiotics in aquaculture. Aquaculture 180:147-165.

Gibson, L.F., Woodworth, J. and George, A.M. (1998). Probiotic activity of Aeromonas media on the Pacific oyster, Crassostrea gigas, when challenged with Vibrio tubiashii. Aquaculture 169:111-120.

Gomez-Gil, B., Roque, A. and Turnbull, J.(2001). The use and selection of probiotic bacteria for use in the culture of larval aquatic organisms. Aquaculture 191:259-270.

Ivanova, E.P., Shevchenko, L.S., Sawabe, T., Lysenko, A.M., Svetashev, V.I., Gorshkova, N.M., Satomi, M., Christen, R., and Mikhailov, V.V. (2002). Pseudoalteromonas maricaloris sp. nov., isolated from an Australian sponge, and reclassification of 
[Pseudoalteromonas aurantia] NCIMB 2033 as Pseudoalteromonas flavipulchra sp. nov. Int J Syst Evol Microbiol 52:263-271.

James, S.G., Holmström, C., and Kjelleberg, S. (1996). Purification and characterization of a novel antibacterial protein from the marine bacterium D2. Appl Environ Microbiol 62:2783-2788.

Jensen, P.R., and Fenical, W. (1994). Strategies for the discovery of secondary metabolites from marine bacteria: ecological perspectives. Annual Rev Microbiol 48:559-584.

Konisky, J. (1982). Colicins and other bacteriocins with established modes of action. Annu Rev Microbiol 36:125-144.

Klaenhammer, T.R. (1988). Bacteriocins of lactic acid bacteria. Biochimie 70:337-349.

Laemmli, U.K. (1970). Cleavage of structural proteins during the assembly of the head of bacteriophage T4. Nature 227:680-685.

Lovejoy, C., Bowman, J.P., and Hallegraeff, G.M. (1998). Algicidal effects of a novel marine Pseudoalteromonas isolate (class Proteobacteria, gamma subdivision) on harmful algal bloom species of the genera Chattonella, Gymnodinium, and Heterosigma. Appl Environ Microbiol 64:2806-2813.

McCarthy, S.A., Johnson, R.M., and Kakimoto, D. (1994). Characterization of an antibiotic produced by an Alteromonas luteoviolacea Gauthier 1982, 85 isolated from Kinko Bay, Japan. J Appl Bacteriol 77:426-432.

Olafsen, J.A. (2001). Interactions between fish larvae and bacteria in marine aquaculture. Aquaculture 200:223-247.

Rayman, M.K., Aris, B., and Hurst, A. (1981). Nisin: a possible alternative or adjunct to nitrite in the preservation of meats. Appl Environ Microbiol 41:375-380.

Ringø, E., and Vadstein, O. (1998). Colonization of Vibrio pelagius and Aeromonas caviae in early developing turbot (Scophthalmus maximus L.) larvae. J Appl Microbiol 84:227-233. 
Robert, R., Nicolas, J.L, and Miner, P. (1996). Mortality control of scallop (Pecten maximus) larvae in the hatchery. Aquacult Inter 4:305-313.

Rosenfeld, D.W., and Zobell, C.E. (1947). Antibiotic production by marine microorganisms. J Bacteriol 54:393-398.

Ruiz-Ponte, C., Samain, J.F., Sanchez, J.L., and Nicolas, J.L. (1999). The benefit of a Roseobacter species on the survival of scallop larvae. Mar Biotechnol 1:52-59.

Schilinger, U., and Lücke, F. (1989). Antibacterial activity of Lactobacillus sake isolated from meat. Appl Environ Microbiol 55:1901-1907.

Tagg, J.R., Dajani, A.S., and Wannamaker, L.W. (1976). Bacteriocins of gram-positive bacteria. Bacteriol Rev 40:722-756.

Thompson, J.D., Higgins, D.G., and Gibson, T.J. (1994). CLUSTAL W: improving the sensitivity of progressive multiple sequence alignment through sequence weighting, position-specific gap penalties and weight matrix choice. Nucleic Acids Res 11:4673-4680.

Venkateswaran, K., and Dohmoto, N. (2000). Pseudoalteromonas peptidolytica sp. nov., a novel marine mussel-thread-degrading bacterium isolated from the Sea of Japan. Int J Syst Evol Microbiol 50:565-574.

Verschuere, L., Rombaut, G., Sorgeloos, P., and Verstraete, W. (2000). Probiotic bacteria as biological control agents in aquaculture. Microbiol Mol Biol Rev 64:655-671. 
Table 1. Characteristics of X153 strain in comparison with those of $P$. piscicida.

\begin{tabular}{lcc}
\hline & X153 & P. piscicida \\
\hline Motility & + & + \\
\hline Growth at & & \\
$\quad 4^{\circ} \mathrm{C}$ & - & - \\
$35^{\circ} \mathrm{C}$ & + & + \\
Pigmentation & Yellow & Yellow \\
\hline Carbone source & & \\
L-arginine & weak & - \\
D-arabinose & - & - \\
D-fructose & - & - \\
D-galactose & - & + \\
D-mannose & + & + \\
melibiose & - & - \\
sucrose & + & - or + \\
glycerol & - & - \\
mannitol & - & - \\
sorbitol & - & - \\
citrate & + & + \\
succinate & + & - \\
\hline 1 Data from Vankateswaran and Dohomoto (2000) and \\
Ivanova et al., (2002). & &
\end{tabular}


Table 2. Antimicrobial activity of X153 against some human pathogenic strains

\begin{tabular}{lccc|}
\hline \multicolumn{1}{c}{ Strains } & Whole culture & Supernatant & Sonicated cells \\
\hline Enterobacter gergoviae & - & - & - \\
Escherichia coli & 1 & 1 & 1 \\
Pseudomonas aeruginosa & - & 1 & - \\
Staphylococcus aureus & 1 & $1 / 2$ & 1 \\
Staphylococcus epidermidis & $1 / 8$ & $1 / 8$ & $1 / 8$ \\
Propionibacterium acnes & $1 / 4$ & $1 / 4$ & $1 / 4$ \\
Propionibacterium granulosum & $1 / 4$ & $1 / 4$ & $1 / 8$ \\
Candida albicans & 1 & - & - \\
Pityrosporum ovale & 1 & 1 & - \\
Aspergillus niger & - & - & - \\
\hline
\end{tabular}

1 : activity without dilution.

1/2, 1/4, 1/8: activity until 1/2, 1/4, 1/8 dilution.

- : inactive. 
Table 3. Antibacterial activity of X153 against marine bacterial strains

\begin{tabular}{|c|c|c|c|}
\hline Strains & Whole culture & Supernatant & Sonicated cells \\
\hline Bacillus globi sp marinus & $1 / 32$ & - & $1 / 8$ \\
\hline Cytophaga lytica & $1 / 32$ & $1 / 4$ & $1 / 32$ \\
\hline Cytophaga marinoflava & $1 / 8$ & $1 / 16$ & $1 / 16$ \\
\hline Deleya marina & $1 / 16$ & $1 / 8$ & $1 / 8$ \\
\hline Halomonas elongata & $1 / 8$ & $1 / 4$ & $1 / 4$ \\
\hline Oceanospirillum jannaschii & $1 / 2$ & $1 / 2$ & $1 / 2$ \\
\hline Pseudomonas doudoroffi & $1 / 4$ & $1 / 8$ & $1 / 4$ \\
\hline Pseudomonas nautica & $1 / 16$ & $1 / 8$ & $1 / 8$ \\
\hline * Vibrio alginolyticus & $1 / 2$ & $1 / 2$ & $1 / 2$ \\
\hline * Vibrio anguillarum & $1 / 2$ & $1 / 4$ & $1 / 4$ \\
\hline Vibrio costicola & $1 / 2$ & $1 / 4$ & - \\
\hline * Vibrio carchariae & $1 / 2$ & $1 / 2$ & 1 \\
\hline Vibrio damsela & 1 & 1 & - \\
\hline Vibrio haloplanktis & $1 / 32$ & $1 / 32$ & $1 / 32$ \\
\hline Vibrio harveyi & $1 / 4$ & $1 / 4$ & $1 / 4$ \\
\hline Vibrio mediterranei & $1 / 8$ & $1 / 2$ & $1 / 8$ \\
\hline Vibrio natriegens & $1 / 4$ & $1 / 4$ & $1 / 4$ \\
\hline * Vibrio parahaemolyticus & $1 / 16$ & $1 / 2$ & - \\
\hline * Vibrio pectenicida & $1 / 8$ & $1 / 2$ & $1 / 4$ \\
\hline Vibrio pelagius & $1 / 8$ & $1 / 2$ & $1 / 8$ \\
\hline Vibrio proteolyticus & $1 / 4$ & $1 / 2$ & 1 \\
\hline * Vibrio splendidus & $1 / 4$ & $1 / 4$ & $1 / 4$ \\
\hline * Vibrio tapetis (P1) & $1 / 8$ & $1 / 8$ & $1 / 8$ \\
\hline Vibrio vulnificus & $1 / 4$ & $1 / 2$ & $1 / 2$ \\
\hline
\end{tabular}

*ichthyopathogenic strain (aquaculture).

1: activity without dilution.

1/2, 1/4, 1/8, 1/16, 1/32 activity until 1/2, 1/4, 1/8, 1/16, 1/32 dilution.

- inactive. 
Table 4. Amino acid composition of P-153

\begin{tabular}{lcc}
\hline & Mole percent & Mol residues / $\mathrm{mol}^{2}$ \\
\hline Asx & 11.0 & 94 \\
Thr $^{3}$ & 5.2 & 44 \\
Ser $^{3}$ & 15.6 & 130 \\
Glx & 15.3 & 129 \\
Gly & 14.3 & 123 \\
Ala & 9.4 & 81 \\
Pro & 4.7 & 41 \\
Val & 4.8 & 42 \\
Met & 0.5 & 4 \\
Ile & 3.5 & 30 \\
Leu & 4.3 & 37 \\
Tyr & 2.0 & 19 \\
Phe & 3.0 & 26 \\
His & 2.1 & 17 \\
Lys & 1.7 & 16 \\
Arg & 2.6 & 22 \\
Trp & ND & - \\
\hline
\end{tabular}

${ }^{1}$ Amino acid composition was calculated from duplicate $24 \mathrm{~h} \mathrm{HCl}$ hydrolysates.

2 Nearest integer values calculated by assuming a molecular weight of 87000 .

${ }^{3}$ Values corrected by extrapolation to zero time hydrolysis.

${ }^{4} \mathrm{ND}$, not determined. 
Table 5. Size and mortality of scallop (Pecten maximus) larvae treated by probiotic bacteria X153. Measurements carried out 16 and 19 days after hatching

\begin{tabular}{lcccc}
\hline & \multicolumn{2}{c}{ Size $(\mu \mathrm{m})$} & \multicolumn{2}{c}{ Mortality (\%) } \\
\hline Experiments & 16 days & 19 days & 16 days & 19 days \\
\hline Control & 194.2 & 215.9 & 20 & 28.3 \\
Control with $\mathrm{Cm}^{1}$ & 196.5 & 221.7 & 0 & 0 \\
$\mathrm{X}^{153-\mathrm{CA}^{2}}$ & 186.2 & 196.3 & $5^{*}$ & $6^{*}$ \\
\hline
\end{tabular}

${ }^{1}$ Control with $4 \mathrm{mg} \mathrm{l}^{-1}$ chloramphenicol (Cm) treatment.

${ }^{2}$ X153 strain cultured in casamino acids medium.

* Mortality significantly different from the control without chloramphenicol. 


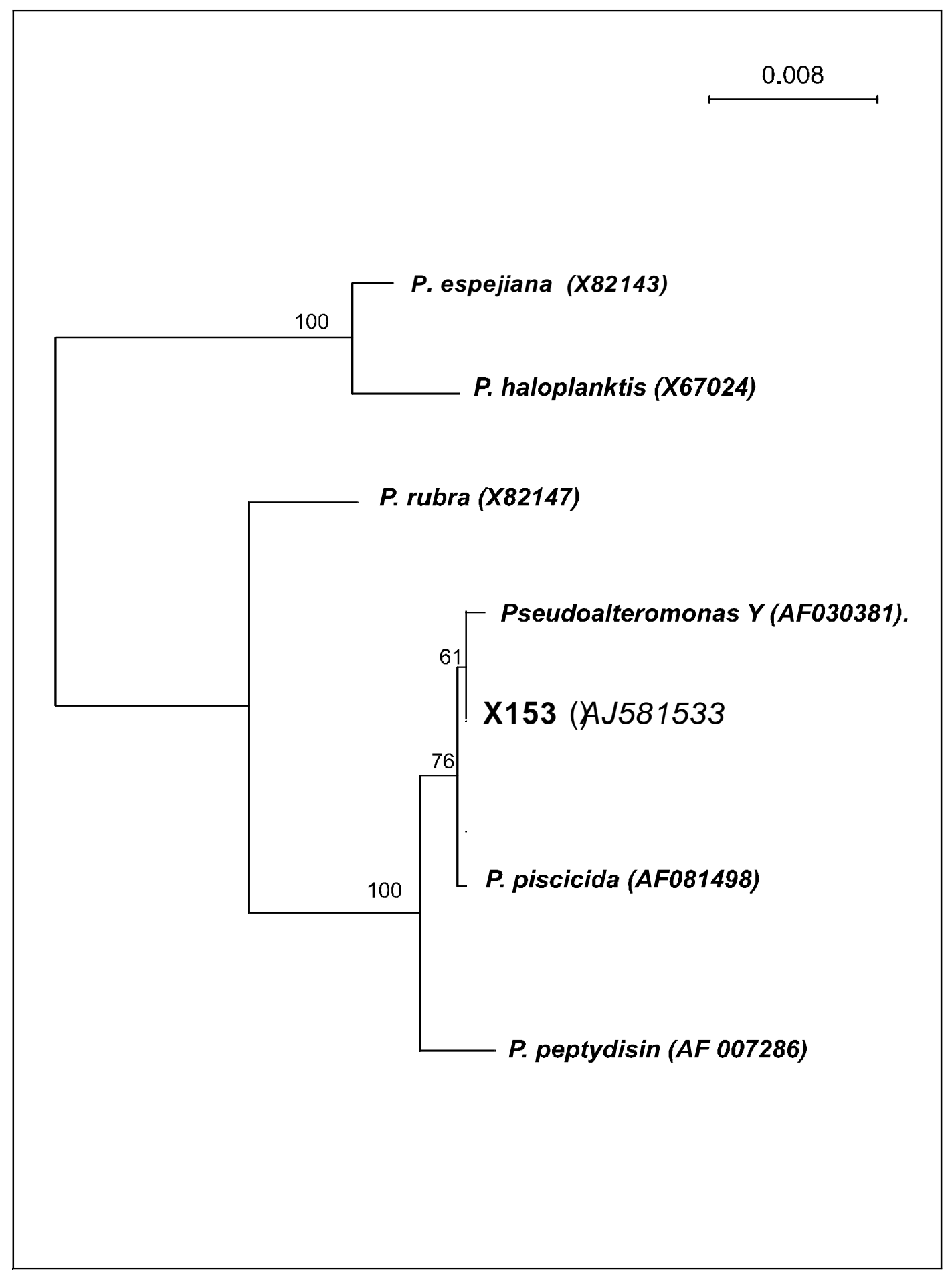

Figure 1 : Phylogenetic tree based on 1139 bp sequence alignment of 16S rDNA genes of X153 strain and closely related Pseudoalteromonas spp. Tree was constructed by the neighbour-joining method. Boostrap values based on the analysis of replicates are indicated at branching points and bar corresponds to 8 substitutions per 1000 nucleotide positions. The accession number of 16S rDNA sequence from EMBL nucleotide database sequence is indicated in brackets. 


\section{(kDa)}
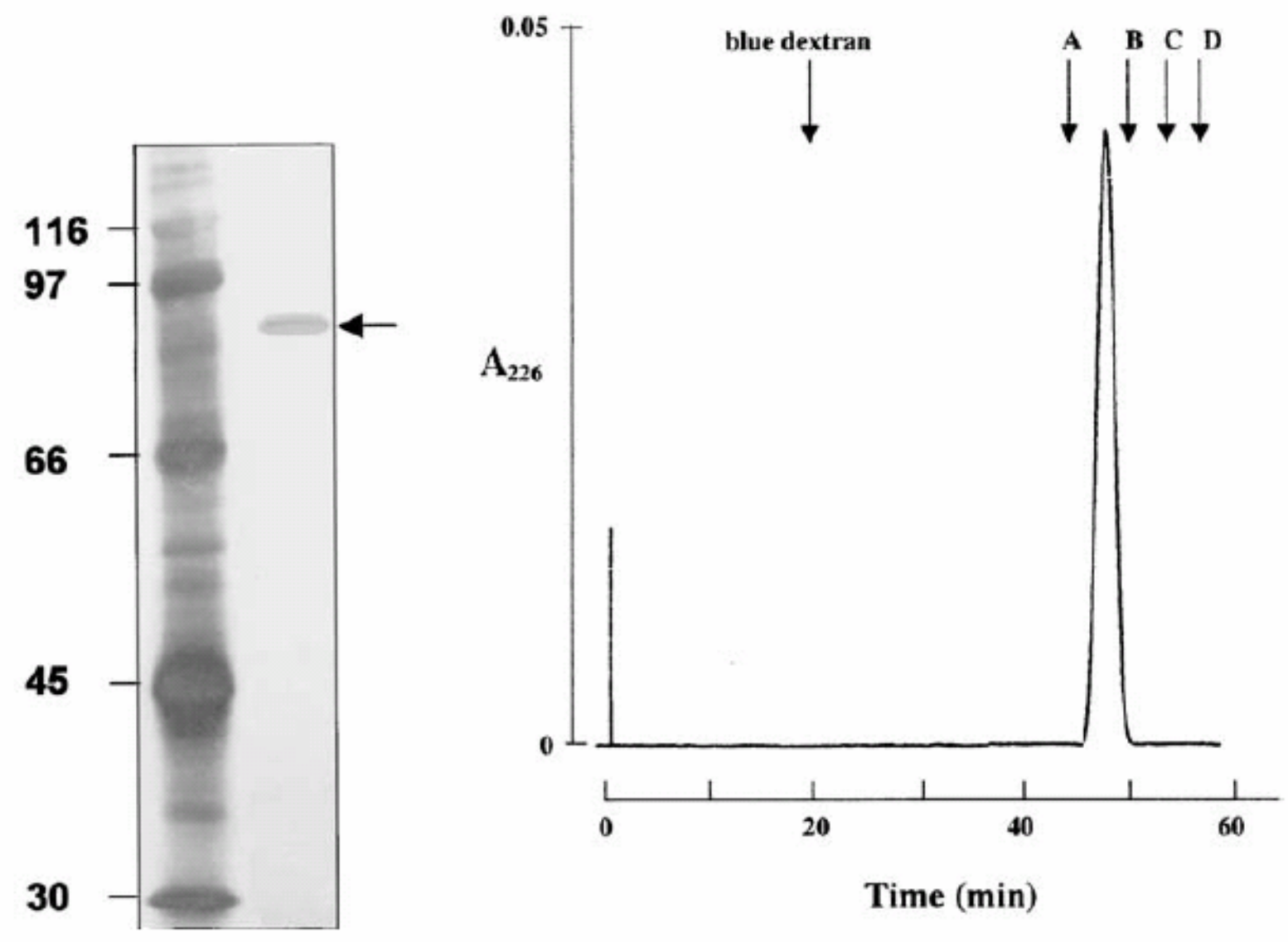

Figure 2. P153 oligomerization.

A: The purified P153 was loaded onto a 4-15\% polyacrylamide gel and silver stained. The molecular mass ladder was the MW-SDS200 kit (Sigma). The arrow is pointing to P153.

B: Size-exclusion HPLC of P153 was performed in $25 \mathrm{mM}$ ammonium bicarbonate, $0.1 \mathrm{M}$ $\mathrm{NaCl}$ on a Superose $6 \mathrm{HR}$ 10/30 column. Separation was performed at a flow rate of 0.3 $\mathrm{ml} / \mathrm{min}$ and absorbance was monitored at $226 \mathrm{~nm}$. Molecular mass markers are apoferritin (443 kDa, A), alcohol dehydrogenase (150 kDa, B), serum albumine bovine (66 kDa, C) and carbonic anhydrase (29, $\mathrm{kDa}, \mathrm{D})$. Void volume is visualized with blue dextran (2000 $\mathrm{kDa}$ ) 